\title{
Listen to the voice of the customer-First steps towards stakeholder democracy
}

\author{
Laura Marie Edinger-Schons ${ }^{1}$ (D) | Lars Lengler-Graiff $^{2}$ | Sabrina Scheidler ${ }^{3}$ (D) | \\ Gina Mende ${ }^{2}$ | Jan Wieseke ${ }^{2}$
}

${ }^{1}$ Chair of Corporate Social Responsbility, University of Mannheim, Mannheim, Germany

${ }^{2}$ Sales and Marketing Department, Ruhr University Bochum, Bochum, Germany

${ }^{3}$ Business Studies and Global Marketing, University of Applied Sciences Dortmund, Dortmund, Germany

\section{Correspondence}

Laura Marie Edinger-Schons, Chair of Corporate Social Responsibility, University of Mannheim, Schloss, 68131 Mannheim, Germany.

Email:schons@bwl.uni-mannheim.de

Funding information

Deutsche Forschungsgemeinschaft, Grant/ Award Number: SCHO 1605/2-2

\begin{abstract}
Recently, calls have grown louder for more stakeholder democracy that is, letting stakeholders participate in the process of organizing, decision-making, and governance in corporations, especially in the area of Corporate Social Responsibility (CSR) activities. Despite the relevance of the subject, the impact of customer involvement in CSR on their company-related attitudes and behaviors still represents a major research void. The paper at hand develops a conceptual framework of consumer involvement in CSR based on the existing literature, theories of stakeholder democracy, and organizational boundaries as well as drawing from the qualitative focus group interviews $(N=24)$. The framework is tested on a large scale, two-time point field-experimental study $(N=3,397)$. More specifically, consumer reactions to three degrees of customer involvement (i.e., information, feedback, and dialogue) are tested in two different CSR domains (i.e., company-internal business process vs. companyexternal philanthropic CSR). Results indicate that the customer involvement in CSR has a more beneficial effect in terms of strengthening customer outcomes in CSR domains that directly affect external stakeholders of the company (i.e., philanthropic CSR) than in domains that mainly concern company-internal stakeholders (i.e., business process $(S R)$.
\end{abstract}

\section{1 | INTRODUCTION}

Customers should have the same right to co-decide how the company allocates its resources as every other member of the stakeholder network. When I was neglected this vote by my favorite soft drink producer 18 years ago, I started a company in which every decision is made in a consensus democratic way. The basic idea is communication on eye-level. Although I see this as a natural thing, it seems to be an innovative business model for many established companies.
Uwe Lübbermann, founder and central moderator of Premium Cola, a consensus-democratic internet collective, winner of the "50 Most Impactful Social Innovators

Award" and consultant for the topic of corporate democracy.

Corporations have increasing power and influence in the public sphere (Grant, 1997; Roach, 2007). Some multinational corporations (MNCs) now own more resources than small countries and have increasing political power (Anderson \& Cavanagh, 1996; Crane \& Matten, 2010). Corporate philanthropic donations are increasing in

This is an open access article under the terms of the Creative Commons Attribution-NonCommercial-NoDerivs License, which permits use and distribution in any medium, provided the original work is properly cited, the use is non-commercial and no modifications or adaptations are made. 
volume and through these donations, companies progressively take over state functions providing important public goods without being democratically elected to do so (McGoey, 2015; Reich, 2006, 2010, 2012; Scherer, Rasche, Palazzo, \& Spicer, 2016). Apart from that, corporations increasingly influence public opinion by funding think tanks and elections, thereby potentially shaping civic discourse (Callahan, 2017). As Scherer et al. (2016) note, businesses not only influence politics but have become political actors themselves and cocreate their institutional environment.

Thinkers from various disciplines have pointed to the potential threat to democracy that such an adoption of political power by business implies (Deetz, 1992; Driver \& Thompson, 2002; Nace, 2005; Scherer, Baumann-Pauly, \& Schneider, 2013). This threat arises because, while an increasing volume of financial resources (including resources used to fund public goods, for example, through CSR budgets) is allocated through big corporations, the governance within most large MNCs is far from being organized in a democratic way (Harrison \& Freeman, 2004; Kerr, 2004; Powley, Fry, Barrett, \& Bright, 2004) and thus lacks legitimacy (i.e., suffers from a "legitimacy gap"; Crane, Matten, \& Moon, 2004; Scherer et al., 2016). Further, apart from the undemocratic allocation process, the consequences of allocation choices of large corporations might not represent the needs and preferences of their stakeholders or the wider public (i.e., a socalled "social issues gap" may exist; Callahan, 2017; Simon, 1995). Very prominently, in a podcast titled "Why Big Philanthropy Needs Scrutiny Not Just Gratitude" Reich (2017) has argued that corporate "philanthropy is an exercise of power and in a democracy, power deserves scrutiny, not just gratitude" (Reich, 2017).

Voices are growing louder which propose that stakeholder democracy (Dawkins, 2014; Matten \& Crane, 2005; Moriarty, 2014; O'Dwyer, 2005; Turnbull, 1994)-defined as letting stakeholders participate in the process of organizing, decision-making, and governance in corporations (Crane, Driver, Kaler, Parker, \& Parkinson, 2005; Fitchett, 2005; Matten \& Crane, 2005)-can be a new pathway to more democratic representation and thus more legitimacy of business. The basic idea is the following: if we unanimously agree that democracy is an important characteristic of our political systems (Harrison \& Freeman, 2004) and if we further accept that corporations have turned into political actors (Detomasi, 2015; Scherer et al., 2016), why should we not demand that they renew their corporate governance structures to be more democratic? Although the power and political activity of corporate actors are omnipresent, the topic has enjoyed very little critical public or research attention (Scherer \& Palazzo, 2011; Scherer et al., 2016). While the conceptual literature on CSR has taken a political turn (Scherer et al., 2016) to discuss the new political power and engagement of businesses, many conceptual and empirical questions remain unanswered. In this paper, we will take a closer look at one specific topic related to making corporate decision-making more participative and thus more democratic, that is, customer involvement in CSR.

The idea of stakeholder democracy is often devalued as unrealistic due to the potential efficiency reduction that could be implied by everybody deciding on everything (Harrison \& Freeman, 2004; Kerr,
2004). One solution to this issue is to elucidate who wants to have a say in which decisions and to design corporate decision making accordingly. In the realm of CSR, for instance, customers might want to have a say on certain CSR topics that are relevant to them but not on others. Taking this as a starting point, we intend to fill voids guided by the following research questions: do customers appreciate to be asked for their opinion on a company's CSR strategy and do they wish to be actively involved in cocreating it? And, importantly, does their degree of appreciation depend on the respective CSR domain?

We address these questions by drawing on existing theoretical contributions on stakeholder democracy, organizational boundaries (Aldrich \& Herker, 1977; Santos \& Eisenhardt, 2005), and stakeholder involvement in CSR (Morsing \& Schultz, 2006). Furthermore, we use qualitative data from focus groups (Study $1, N=24$ ) to develop a conceptual framework of customers' involvement in CSR in different CSR domains which either concern company-external (i.e., customers) or company-internal (i.e., employees) stakeholders. More specifically, based on the findings of our focus group study, we argue that customers appreciate being involved in CSR decisions that concern company-external stakeholders and not in those that are internal to the company. We empirically test this framework in a large-scale field-experimental study including two-time points of measurement (Study 2, N=3,397) which we conduct in collaboration with a large international retailer. More specifically, the effects of the three different degrees of customer involvement (based on Morsing \& Schultz, 2006, that is, information, feedback, and dialogue) are tested in two different CSR domains (i.e., philanthropic CSR, that is, donations vs. business-process CSR, that is, employee support).

Supporting our theorizing, results indicate that customer involvement in CSR has a more positive effect on customers' identification with the company and loyalty in domains that affect external stakeholders of the company (i.e., corporate philanthropy) than in CSR domains that mainly concern company-internal stakeholders (i.e., employee support as a form of business process CSR).

The results of our two studies make several contributions to theory building and to managerial practice. First, we contribute to research on stakeholder democracy by generating empirical evidence on customers' preferences for being involved in decision-making in the CSR domain. Eliciting stakeholders' preferences for cocreation may be a fruitful path to develop feasible methods of stakeholder democracy that would maximize participation and support. Second, we contribute to the theoretical discussion on the borders of the organization by pointing out that the CSR domain (i.e., company-internal business process CSR vs. external philanthropic CSR) moderates the beneficial impact of customer involvement in CSR on customer outcomes. Our results reveal that customers consider themselves as a part of the organization in areas in which the organization has a strong impact on societal outcomes (i.e., corporate philanthropy) and in which, thus, the line between the inside and the outside of the organization is blurred. However, in areas that mainly concern the internal business processes of the corporation (e.g., employment practices) customers do not appreciate to be involved in 
CSR decision-making. Third, by exploring the effects of customer involvement in CSR on the dependent variables of customer-company identification and loyalty, we contribute to the extant research that shows how CSR can strengthen the customer-company bond (Haumann, Quaiser, Wieseke, \& Rese, 2014). Obviously, dialogue with customers concerning the company's CSR can be an especially effective tool to establish and reinforce these social bonds.

Our study also generates implications for managerial practice. Companies should be aware of their relationship with society, and more specifically, the degree to which they affect outcomes related to various stakeholder groups in different areas of organizational decision-making. Management should be cognizant of the relevance to hear the voices of the stakeholders that are affected by the corporate decision in these areas.

In the remainder of the manuscript, we will proceed as follows. In the upcoming section, we will provide a brief overview of the existing literature on stakeholder democracy, CSR communication, and customer involvement in CSR. Then, we will present the results of our first, qualitative, study and use them to derive our researchpropositions on customer involvement in CSR. We will test these propositions in our quantitative field experiment. Finally, we will discuss the results of the paper at hand in light of their implications for theory and managerial practice.

\section{2 | REVIEW OF EXISTING LITERATURE}

\section{1 | Toward a more democratic allocation of CSR budgets}

Interestingly, although the individual is the foundation of every democratic system, the microlevel is so far the least researched level in contributions to political CSR and stakeholder democracy. Based on a survey and content analysis of 146 academic articles, Frynas and Stephens (2015) state that "our survey suggests that the individual level of analysis is the least studied and the least theorized level of analysis" (p. 508). On the level of individual managers, employees, and consumers, many aspects remain uncharted: the awareness of corporate power and a potential need for more corporate democracy, individuals' attitudes toward corporate philanthropy and corporate political activity, and individuals' willingness to engage in active behaviors to promote democracy in organizations. Further, up to now, no studies have aimed to identify individual-level factors that promote or hinder transformation processes within stakeholder networks toward more corporate democracy (Scherer et al., 2013).

In this paper, we propose that customer involvement in CSR (as one form of stakeholder engagement, Griffin, 2017) can be a first important step toward a more democratic allocation of corporate resources. The allocation of corporate philanthropic budgets is an area for which a development toward more participative decisions would be especially important due to the following reasons: by spending substantial budgets on philanthropic causes, companies provide important public goods, and thereby assume a state-like role. The responsibility for this redistribution of income, however, usually lies in the hands of very few people. Interestingly, little is known about the factors that guide a company's donation allocation decisions. In the 1980s, Useem (1988) described that $70 \%$ of firms reported that the influence of the CEO on both the size and the nature of giving programs exceeded that of all other factors. Recently, many companies have developed CSR missions (many of them based on the UN Sustainable Development Goals) to guide their giving, as, for example, SAP's "equip the world's youth with the skills they need to tackle society's problems and thrive in the digital economy." However, the development process and justifications of these CSR missions are, to date, still a black box, too. Against the background of an increasing volume of corporate philanthropic spending, companies should reconsider the processes by which they allocate these resources to social causes. This is especially important as unpopular social causes (we could call them "stigmatized social causes") such as NGOs supporting women in prostitution, or patients suffering from HIV or mental diseases, might miss out on corporate donations which often seem to be allocated based on their potential to enhance the company's external image (Body \& Breeze, 2016). The evolving field of CSR communication and stakeholder engagement and dialogue plays a crucial role in this regard as it is the communication channel that spans the boundary between company internal CSR managers and the company's stakeholders (Richter \& Dow, 2017). Engaging in an ongoing dialogue may enable a more democratic allocation of these budgets. However, current approaches to CSR communication and stakeholder engagement are still far from this ideal. In the following, we include a brief review of the existing research on CSR communication and customer involvement in CSR.

\section{2 | Traditional approaches to CSR communication}

To increase customers' awareness and knowledge of a company's CSR strategies, these activities have to be communicated. Traditional CSR communication has often been viewed as a persuasive attempt of the company to positively influence customers' perceptions (Nielsen \& Thomsen, 2009; Vanhamme \& Grobben, 2009). However, CSR communication can yield negative results if a CSR commitment is suspected to be driven by purely egoistic motives, such as trying to reap positive customer outcomes and thereby profit by engaging in a good deed (Du, Bhattacharya, \& Sen, 2007; Ellen, Webb, \& Mohr, 2006; Fein \& Hilton, 1994; Forehand \& Grier, 2003; Morsing, 2006). Thus, such traditional forms of CSR communication are a double-edged sword, where too much or wrongly perceived information quickly backlashes on a company's ambition to position itself as socially or environmentally responsible (Yoon, Gürhan-Canli, \& Schwarz, 2006).

Though holistic empirical studies on CSR communication remain scarce, there is an increasing body of knowledge addressing specific aspects of CSR communication. Existing contributions concern the timing of the communication, the chosen channel, and the communication spending. For instance, one of the core questions is whether a company should communicate their CSR commitment proactively (preventive CSR communication, Du et al., 2007; Shimp, 1997) or 
reactively (statements after negative publicity, Murray \& Vogel, 1997). Customers generally perceive proactive communication as more positive due to its seemingly altruistic nature (Becker-Olsen, Cudmore, \& Hill, 2006). However, studies relating to the "how to" often focus on crisis settings (Wagner, Lutz, \& Weitz, 2009; Yoon et al., 2006). Some studies have scrutinized the specific factors related to customers' perceptions of CSR communications like CSR fit, motives, or issue importance (Pérez, de los Salmones, \& Liu, 2019).

Despite a growing discussion around stakeholder engagement, stakeholder dialogue, and stakeholder involvement in large MNCs as well as in SMEs (Morsing \& Perrini, 2009) and despite the fact that conceptual contributions have outlined possibilities to engage with stakeholders in two-way, dialogic communications processes (Morsing \& Schultz, 2006), to our knowledge, no existing studies have so far focused on exploring the effect of different CSR involvement strategies on perceptual and behavioral outcomes of customers. Empirical research hence seriously lacks insights that can provide guidance for designing proactive, dialogic CSR communication, which is also of core importance for practitioners (Ogilvy Public Relations Worldwide, 2010). In the following, we will provide a review of the existing literature on customer involvement in CSR as one form of stakeholder engagement.

\subsection{Customer involvement in CSR}

Recently, many companies have developed new approaches to involve customers in their CSR strategies, especially in the area of cause-related marketing. Sun Trust Bank, for instance, donated $\$ 100$ to a cause chosen by customers who open a new checking account. Other companies like Vodafone try to establish a more profound dialogue with their customer base to learn about their attitudes toward different CSR activities and subsequently integrate this feedback into their CSR-related decisions.

Despite an "urgent need for both academics and practitioners to get a deeper understanding of how to communicate CSR more effectively to stakeholders" (Du, Bhattacharya, \& Sen, 2010, p. 17), customer involvement in CSR represents a major research void. Although first evidence on positive effects has been generated in experiments featuring cause-related marketing settings (Robinson, Irmak, \& Jayachandran, 2012), research on the effect of a more profound involvement of customers into the CSR strategy-building of the company is, as far as we know, still lacking.

Among those reviewed, only one single paper has so far highlighted the positive impact of giving customers the chance to choose a cause on their reactions to cause-related marketing campaigns. According to Robinson et al. (2012) customers evaluate these kinds of campaigns favorably due to a higher degree of involvement and control. Furthermore, they rate campaign outcomes more favorably as these outcomes match their preferences. Finally, involvement also increases customers' attachment to the chosen cause.

Moreover, past research has conceptually outlined different intensities of customer involvement in communicating CSR activities to stakeholders (Morsing \& Schultz, 2006) and identified three main strategies: first, the stakeholder information strategy, second, the stakeholder response strategy, and third, the stakeholder involvement strategy. Within their framework, the stakeholder information strategy refers to one-way communication, that is, from the organization to its stakeholders. The goal is to tell and to persuade, not to listen or to understand. Tools to reach this goal can be press relations, brochures, pamphlets, magazines, etc. In contrast to this, the response strategy is based on two-way asymmetric communication. This means that the company communicates to its stakeholders and listens to their response, but they do not necessarily change or adjust as a reaction to this feedback. The basic goal still is to change public attitudes and behavior. The involvement strategy, finally, assumes a dialogue between company and stakeholders in which both try to persuade each other and both parties experience a change due to the communication. Thus, these options cover the gradual development from a classical monologue (i.e., information giving) to more mutual and dialogue-based stakeholder relationships (i.e., seeking feedback and engaging in an ongoing dialogue).

The framework of Morsing and Schultz (2006) is based on the assumption that the degree to which an organization is able to integrate the sense-making of others into their decisions will influence the organization's ability to build up productive relationships and to move away from managing stakeholders toward a relational and process-oriented view on the interactions that they have with stakeholders. The authors claim that "there is an increasing need to develop sophisticated two-way communication processes (sense making and sense giving) when companies convey messages about CSR" (p. 325). Interestingly, whereas all three levels of stakeholder involvement are implemented in business practice, no empirical research has so far investigated their comparative impact on customers' perceptions and behavior.

The stakeholder information strategy will be referred to as "information strategy" in this paper, the stakeholder response strategy as "feedback strategy," and the stakeholder involvement strategy as "dialogue strategy." Due to a lack of literature on customer involvement in CSR communication, we decided to first use a qualitative approach to elicit customers' preferences for involvement in CSR. The results of these focus groups are applied to derive our conceptual framework in the subsequent section.

\section{3 | STUDY 1: CSR DIALOGUE ACROSS ORGANIZATIONAL BOUNDARIES}

\section{1 | Study design}

We conducted interviews with four focus groups using a small-group approach with six participants each. The groups differed in age and occupational status. The first group was composed of participants aged between 21 and 24 (students in economics and business administration), the second also covered an age range between 22 and 24 (students from a diversity of faculties), the third group was composed of participants aged between 22 and 32 (all employed), 
and the fourth group was also a group of employed people with the age ranging from 40 through 60 years. Thereby, we ensured that participants' characteristics varied significantly between groups (to accommodate alternative views on the subject), but only to a certain extent within groups to ensure an atmosphere where all participants felt comfortable to discuss their ideas. Given the sensitive issues of the interviews (e.g., questions on moral views), the chosen approach seems appropriate to mitigate a potential social desirability bias.

\section{2 | Procedure}

The focus group interviews were conducted by a researcher trained in qualitative research approaches. To ensure a common understanding of CSR, the interviewer opened the discussion with the question of whether the participants had an idea of what the term "corporate social responsibility" means and which facets it encompasses. This proceeding is in accordance with recommendations to explain and define the subject before delving into more detailed discussions when interviewees are expected to have very heterogeneous starting points of knowledge (Dürrenberger, Kastenholz, \& Behringer, 1999).

After discussing participants' understanding of CSR, the interviewer provided each participant with a printed version of the definition of CSR according to the DIN ISO26000 (2011) and explained the different domains that can be understood as CSR engagement. The definition reads as follows:

"Responsibility of an organization for the impacts of its decisions and activities on society and the environment, through transparent and ethical behavior that:

- contributes to sustainable development, including health and the welfare of society;

- takes into account the expectations of stakeholders;

- is in compliance with applicable law and consistent with international norms of behavior;

- and is integrated throughout the organization and practiced in its relationships"

Thereby, the interviewer encouraged participants to come up with own examples, experiences, and thoughts about the subject. We granted no financial incentives for taking part in the study. After the interviews were finished, the interviewer thanked participants for their contribution and informed them about the purpose of the study in a debriefing.

All participants agreed that the interviews were audio-recorded. Afterwar, we transcribed all interviews for the analysis.

\subsection{Results and hypotheses development: Customer involvement in CSR}

In general, the results of the focus group interviews tie in very well with the recent results of research that show that customers appreciate being involved in philanthropic CSR decisions (Robinson et al., 2012). For instance, one participant referred to the example of the German brewery "Krombacher" which used a cause-related marketing campaign in which the company promised to save one square meter of rainforest for every crate of beer bought: "If Krombacher would ask me to decide where the money should be donated to, I would definitely appreciate that. I would feel that these things are less abstract for me and I would probably have the feeling that the money really reaches the intended recipients." As the quote indicates, the discussion in the focus groups revealed that being involved in philanthropic CSR decisions makes customers feel appreciated, makes them feel attached to the CSR activity and the company, and enhances their trust in the activity. Further, the discussions revealed that customers even feel entitled to have a say in these decisions because they financially support the company through their purchases. To exemplify, one participant explained: "When I pay for a product and the company uses a part of the money to support good causes, I would really like to have a say about where the money goes to."

As a consequence of being involved, the participants reported an elevated intention to remain a loyal customer of the company. To exemplify, one participant put it as follows: "If I spend money for a product, I somehow feel related to the company. I would rather want to spend my money on products from those companies that ask me where I would like to donate the money to. I would like to support such efforts."

The discussion in all four focus groups further circled around the aspects of identification with the organization. Importantly, many quotes from the interviews indicate that being asked to join the company's decision-making on CSR topics enhances customers' feeling of being active and contributing a part of the organization. This leads to an increase in customer-company identification. This is underlined by quotes from all focus groups. One participant, for instance, expressed: "I would probably feel appreciated by the company and would feel as if I was a part of the company myself." Another participant stated: "I would like to tell others about how socially responsible the company acts and I would feel proud to be a customer of the company."

Recent research has revealed that customer-company bonds are important predictors of customer loyalty, even outperforming classical marketing metrics such as customer satisfaction (Haumann et al., 2014). A strong connection between customer and company does not only lead to stronger intentions to repatronize the company. In their empirical test of organizational identification in the context of customer-company relationships, Ahearne, Bhattacharya, and Gruen (2005) investigate whether customers identify with companies and what the antecedents and consequences of such identification are. Their model posits that informational cues such as perceived company characteristics, construed external image, and the perception of the company's boundary-spanning agents lead to customers' identification with a specific company. The fact that the company engages in proactive stakeholder dialogue concerning CSR could very well represent such an informational cue and thereby enhance customers' identification with the company. Based on these findings we propose: 
Hypothesis 1 Customer involvement in CSR has a positive effect on customers' loyalty.

Hypothesis 2 Customer involvement in CSR has a positive effect on customers' identification with the company.

However, besides these overall positive attitudes toward involvement, the discussions in the focus groups also indicated important contingencies. First, participants repeatedly stressed the fact that being involved in company decision-making increases the company's costs of coordination and that, thus, a certain level of efficiency would have to be ensured. This becomes very obvious when one imagines that consumers purchase various different goods on a daily basis. Obviously, it would be impossible to be involved in the corporate decision making of each of those brands. For instance, one participant stated: "If companies would involve customers in all kinds of decisions, even those that do not have a direct benefit for them, that would definitely go too far and would not be efficient."

Second, the focus group discussions uncovered that participants would appreciate being involved in CSR activities that are relevant to their own lives but would rather not want to be involved in those that are not. To illustrate, one participant clearly articulated: "I would like to be asked for my opinion on CSR topics that are relevant for me." The other participants agreed and the discussion in all four focus groups made the importance of this point evident.

Another participant explained: "It would feel strange if a company would ask me to make decisions about their core processes because I'm not a part of the core company, but I would like to be involved in decisions that have a link to my life." The notion of CSR activities that are central to the company's value chain processes (e.g., employment practices) versus activities that are located "outside of the company," for example, philanthropic CSR engagement, was central to the discussion in all four focus groups. For example, one participant put it as follows: "I think it would make sense if companies would involve customers in company-external decisions, as, for example, decisions on projects in local communities, but not in decisions that lie at the heart of the company." Participants agreed that they would not feel that the internal value chain decisions of the company are relevant to them (except if they were not a customer but an employee of the company) and thus argued that they would not see any sense in codeciding about these activities. Besides the lack of relevance for them, all discussions revealed that another rationale for not wanting to be involved in company-internal decision making is that participants felt they would not have the necessary competences to do so. One participant explicitly said: "As a layperson and someone who does not have insights into the internal business processes of the company I would not feel competent to comment on them."

These results tie in very well with existing theories on organizational boundaries. According to Aldrich and Herker (1977), crossing organizational boundaries in communicative processes serves two goals, that is, information processing and external representation. In their comprehensive treatment of organizational boundaries, Santos and Eisenhardt (2005) define four boundary conceptions, that is, efficiency, power, competence, and identity that can be used to maximize the efficiency of organizational boundaries from the organization's strategic perspective. Organizational boundaries define the boundary between an organization and its environment (Santos \& Eisenhardt, 2005). Given newer approaches to management that view the organization as a nexus of stakeholders that all have interests in the organization, the notion of organizational boundaries deserves some fresh research attention. Do customers view themselves as a part of the organization or as a part of the organization's environment? Interestingly, many of the arguments brought up in the boundary conceptions defined by Santos and Eisenhardt (2005) were mentioned during the focus group interactions. Obviously, customers regard themselves as a part of the organization in areas of decision making in which they are directly affected and in which they can make an informed judgment. In summary, due to considerations of efficiency, relevance, and competence, customers appreciate being involved in philanthropic CSR activities that are more "external" to the company but do not wish to be asked to codecide on CSR activities related to the business process that are more "internal" to the company. As a consequence, we propose that the effect of customer involvement in CSR will be more positive for company-external philanthropic CSR activities than for company-internal business process activities. More formally:

Hypothesis 3 The CSR domain moderates the effect of involvement on the customer-company identification and loyalty in a way that the effect of involvement is more positive for philanthropic CSR than for business-process CSR.

\section{4 | STUDY 2: A FIELD-EXPERIMENT ON CUSTOMER INVOLVEMENT IN CSR}

\section{1 | Design}

In this second study, we test how the different degrees of customer involvement (i.e., information, feedback, and dialogue) affect customer-company identification and loyalty depending on the specific CSR domain (i.e., either focusing on company-internal philanthropic vs. external business process CSR activities).

To test our conceptual framework, we conducted a large between-subjects field-experiment $(N=3,397)$ in collaboration with the German branch of a well-known international retail company. The partner company allowed us to send out messages to the companies' customers (who had previously given their consent to be contacted) via the company e-mail newsletter. We communicated the study to the customers as a collaboration between the partner company and the team of researchers.

In the $3 \times 2$ between-subjects experiment, we manipulated the degree to which customers were involved in the CSR communication (i.e., information, feedback, and dialogue) and varied the CSR domain (i.e., company-external philanthropy vs. internal business-process CSR). Customers were randomly assigned to one of the resulting six groups. Figure 1 illustrates the experimental groups. 


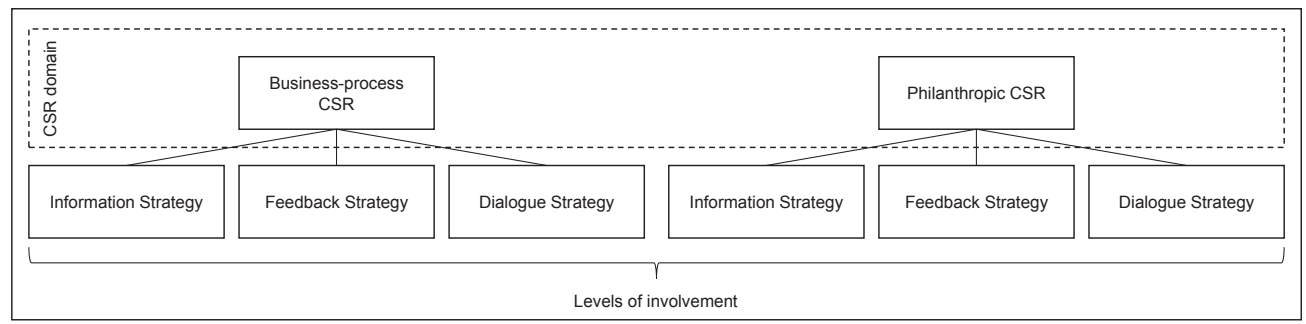

FIGURE 1 Experimental groups

The information groups only received information about the current CSR project of the company. The feedback groups received the same information but were additionally asked to provide their feedback on the project. The customers in the dialogue groups received the same CSR information as the previous two groups, were asked to provide their feedback on the project and were asked to suggest which types of CSR activities the company should more intensively engage in in the future. In $t_{2}$, six weeks after the first newsletter was sent out, the dialogue groups received a report on the results from $t_{1}$ including the key take-away from the customer survey and they were informed that the company would take their preferences into account when designing future CSR activities. The other groups were merely asked to participate in the follow-up survey and did not receive any further treatment information.

Moreover, the communicated CSR activities were varied by the CSR domain. In the philanthropy groups, participants received information on activities about a recent philanthropic CSR activity of the company supporting poor children in Pakistan. In the business process CSR groups, participants received information about a new employee support activity that the company had recently implemented to enhance employees' work-life balance. In $t_{2}$, we measured our dependent variables.

Having been exposed to these different treatment conditions, customers were asked to rate their loyalty intentions as well as their level of customer-company identification in $t_{2}$ (both scales by Homburg, Wieseke, \& Hoyer, 2009). We also measured a comprehensive set of control variables, for example, customer satisfaction, affective commitment, gender, age, and educational level. For an overview of all measurement scales, please see Appendix A.

\section{2 | Instrument}

All treatment groups received a short text about one of the company's CSR activities. For instance, the philanthropy groups received the following information:

Child poverty, oftentimes turning children into beggars, is a particularly large problem in Pakistan's urban areas. Only 63\% graduate from elementary school. [COMPANY NAME] wants to contribute toward providing education to more children in Pakistan. The [COMPANY NAME] Foundation supports the [NGO NAME] Organization through both financial aid and commodity contributions. The Foundation gives many children a future, which protects them from poverty and allows them to find a regular job later on.

The business-process CSR groups received the following information:

[COMPANY NAME] supports employee childcare. To help employees find a better work-life balance, [COMPANY NAME] has implemented an improved childcare service for employees at its headquarters in [PLACE OF COMPANY HEADQUARTER]. The daycare facility is located close to company headquarters and, compared to other local childcare facilities, it has smaller group sizes and is open for longer hours (until 6 p.m.). Many employees are already using this new service.

The information groups only received this information. The feedback groups additionally received the request to rate their opinion of the CSR activity based on the following items.

"As a customer of [COMPANY NAME], your opinion about the social projects is very important. Please let [COMPANY NAME] know what you think about the project."

- "How do you like this activity overall?" (7-point Likert scale ranging from "not at all" to "very much")

- "What is good, what may be improved?" (open text box)

- "Do you appreciate that [COMPANY NAME] asks you to give feedback to this activity?" (7-point Likert scale ranging from "not at all" to "very much")

The dialogue groups received both of the above treatments and were, in addition to that, asked to rate which activities they would like to see the company to engage in in the future:

"[COMPANY NAME] wants their customers to be involved in the planning and further development of future social and environmental projects. As a customer of [COMPANY NAME] you have a decisive vote."

- "Should [COMPANY NAME] increase its support of following domains?

- Philanthropic donations

- Environmental Sustainability 
- Local Community Support

-Employee Support"

(7-point Likert from disagree to agree for each domain)

- "Do you appreciate being involved in the planning?" (7-point Likert scale ranging from "not at all" to "very much")

The respondents in these dialogue groups were informed about the results of the survey and the intention of the company to take customers' opinions into account in $t_{2}$ (six weeks after $t_{1}$ ).

\section{3 | Pretest of the treatments}

To make sure that our treatments worked as intended, we conducted a pretest among 184 Amazon Mechanical Turk participants (MTurk). We conducted the pretest as a $3 \times 2$ (three levels of in volvement, two types of (SR) between-subjects scenario experiment. Within the information groups, 32 respondents received the employee CSR treatment and 32 the philanthropy treatment. In the feedback group, 25 respondents received the employee CSR treatment and 32 the philanthropy treatment. Finally, in the dialogue groups, the cell sizes were 33 for employee CSR and 30 for philanthropic CSR. About $34 \%$ of the respondents were female and the average age was 51.

As a manipulation check, we included five items in the form of Likert scales ranging from 1 = "I do not agree at all" to 7 = "I fully agree" capturing whether respondents perceive the company to engage in business process CSR. Sample items include "[COMPANY NAME] engages in socially responsible business practices for their employees." Further, we included 5-Likert scale items with the same scale endpoints to capture participants' perceptions of the company's philanthropic CSR. An example of an item on this scale is "[COMPANY NAME] engages in philanthropic activities." The full list of items and the results of the manipulation check are summarized in Appendix B.

We compared the means on these items across the business process and the philanthropic CSR groups and all mean differences support the proposition that our treatments worked as intended. Respondents' perceptions of the company's business process CSRrelated activities are higher in the business process CSR groups and their perceptions of the company's philanthropic CSR are higher in the philanthropic CSR groups.

Further, we included four items to capture whether respondents correctly understood whether the company merely informs customers about their CSR (highest means in the information groups), provides them with the opportunity to give feedback (highest means in the feedback groups), or whether they actively seek customers' opinion and involve customers in the CSR decision-making process (highest means in the dialogue groups). Thus, the pretest fully supports that our experimental manipulations worked as intended. The results of the pretest are reported in more detail in Appendix B.

\section{4 | Sample}

Our survey was mailed to an initial sample of 22,646 customers of the company. About 3,397 respondents completed the questionnaire which implies an answering rate of approx. 15\%. About $76 \%$ of the respondents are female ${ }^{1}$ with an average age of 37 . Within the information groups, 550 respondents received the employee CSR treatment and 486 the philanthropy treatment. In the feedback groups, 655 respondents received the employee CSR treatment and 687 the philanthropy treatment. Finally, in the dialogue groups, the cell sizes were 513 for employee CSR and 506 for philanthropic CSR.

\section{5 | Data collection}

The data were collected using the online survey tool efs survey. Participants were asked to take part in the questionnaire which was sent out via the company e-mail newsletter. As incentives for participation, shopping vouchers were raffled among the respondents who fully completed the questionnaire. The questionnaire was programmed as a series of web pages. Customers could not return to the previous page to modify their answers and had to answer all questions to proceed to the next page. In a technical introduction, customers received a detailed explanation of how to answer the multi-item Likert scales.

\subsection{Scale evaluation}

All multi-item scales reported in Appendix A show a high degree of reliability and validity. All constructs were measured on 7-point Likert scales with the endpoints of the scale labeled as "I do not agree at all" and "I fully agree." The confirmatory factor analysis (CFA) measurement model for customer-company-identification fits the data well and the values for coefficient alpha ( $\geq .94), C R(\geq .94)$, and AVE ( $\geq .78)$ exceed the critical values (Bagozzi \& Yi, 1988; Nunnally, 1978). For the factor of loyalty, the CFA measurement model fits the data well, too. All critical values were exceeded: for coefficient alpha ( $\geq .91), \mathrm{CR}(\geq .90)$, and $\operatorname{AVE}(\geq .62)$.

\section{7 | Method}

We used ANOVAs to test for the direct effects of the treatments on the customer-company identification and loyalty. In a second step, we used the SPSS process to test for the moderation proposed in $\mathrm{H}_{3}$. Within the SPSS process, we estimated Model 1 with the involvement treatment as an independent variable, philanthropy versus employee CSR as a moderating variable, and the customer-company identification and customer loyalty as dependent variables. 


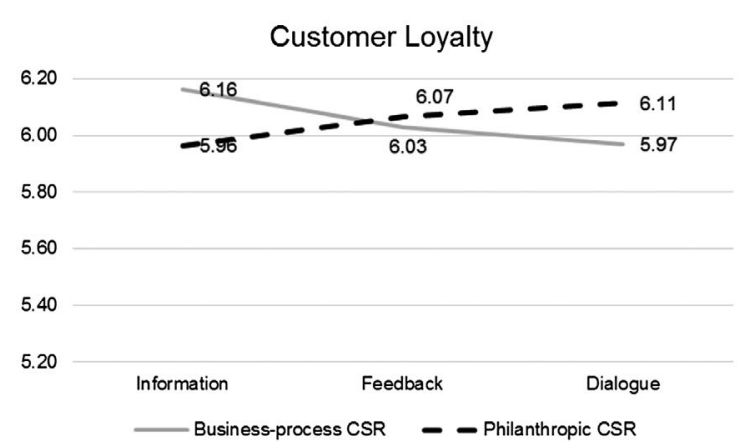

FIGURE 2 Study 2-Mean differences across groups

\subsection{ANOVA results}

We used SPSS Statistics 23 for all analyses. Figure 2 presents a summary of the overall experimental effects, whereby the dependent variables are customer-company identification and customer loyalty.

Results indicate that customer-company identification $(F(2$, $3,397)=.724$, n.s. $)$ and loyalty $(F(2,3,397)=.052$, n.s. $)$ do not vary significantly across the different involvement strategies and across the two different CSR domains (customer-company identification: $F(1,3,397)=.682$, n.s; customer loyalty: $F(1,3,397)=.014$, n.s.), but that there is a significant interaction effect between involvement strategy and CSR domain (customer-company identification: $F(2$, $3,397)=7.436, p<.001$; customer loyalty: $F(2,3,397)=3.132, p<$ .050) which supports our third hypothesis. This significant interaction effect indicates that customer involvement in CSR has a significantly more beneficial effect in terms of strengthening customers' identification with the company in domains that affect external stakeholders of the company (i.e., corporate philanthropy) than in CSR domains that mainly concern company-internal stakeholders (i.e., employee support as business process CSR). Thus, our results provide us with convergent support for our hypothesized moderation by the CSR domain. To explicitly test the moderation, we estimated the model as described above in the SPSS process. Results confirm the ANOVA results. More specifically, the interactions between the involvement treatment and the dummy for philanthropic CSR are significant and positive for both dependent variables customer-company identification $(\beta=.173 ; p<.050)$ and loyalty $(\beta=$ $.183 ; p<.050$ ), indicating that the effect of involving customers is more positive for philanthropic than for business-process related CSR. It is important to note that the significant effects of the treatment are time-delayed, as we measured customer-company identification and customer loyalty six weeks after sending out the first treatments.

As a robustness check, we ran the same analysis for varying customer outcomes which we had measured as potential controls, that is, customer satisfaction and affective commitment. We find the same significant interaction effect for both alternative outcome variables affective commitment $(\beta=.118 ; p<.050)$ and customer satisfaction $(\beta=.115 ; p<.050)$.

\subsection{Checks}

Robustness checks confirm that the imbalanced gender distribution of the sample does not bias the results. We conducted separate ANOVAs with customer-company identification as a dependent variable, the different treatments as independent variables, and gender as a moderating factor. To avoid interpretation problems of the ANOVA result due to imbalanced group sizes, we drew a random sample from the female group to match group sizes. We did not find any moderating effect of gender.

To check for nonresponse bias, we compared the demographic data of the customers who responded to our surveys to those of nonrespondents using data retrieved from company records. The results indicate that respondents and nonrespondents are comparable to the demographic criteria of age, sex, income, and education.

Common method variance (CMV) can be a problem in any single-source survey-based that uses the same type of scales (i.e., Likert-scales). Therefore, we took several precautions to rule out the presence of CMV in our analysis. First, the independent variables are experimental manipulations and not survey constructs. Second, we assured the participants that their answers would be processed anonymously to minimize socially desirable response patterns (Podsakoff, MacKenzie, Lee, \& Podsakoff, 2003). Third, we conducted Harman's single factor test in line with the recommendation of Podsakoff et al. (2003). The unrotated factor solution revealed two factors with Eigenvalues greater than one, accounting for $78.40 \%$ of the total variance (the first factor accounts for $62.45 \%$ of the total variance). These results strongly suggest the absence of a single general factor in the data set, which along with the experimental manipulation and the anonymity of answers suggest that the threat of common method bias is not serious.

\section{5 | GENERAL DISCUSSION}

The spirit of democracy is not a mechanical thing to be adjusted by abolition of forms. It requires a change of heart. (Mahatma Gandhi) 


\section{1 | Summary of results}

The study at hand uses qualitative and quantitative empirical data to explore customer reactions to being involved in the CSR strategy of a company. Our first, qualitative, study provides interesting insights into customers' preferences concerning this involvement. Customers obviously appreciate to be asked for their opinion and to be actively involved in the CSR activities of companies. However, their preferences for the involvement depend on the CSR domain. While they wish to be involved in CSR domains which are company-external and which are thus more relevant for external stakeholders (i.e., corporate philanthropy), they do not wish to be involved in company-internal CSR decisions (i.e., business process CSR). We juxtapose these qualitative insights with existing theory and derive our research model. The empirical test of the model in our second, quantitative, study, generates support for our basic theorizing. Over and above, the quantitative study provides some additional insights that deserve attention and which we will discuss in the light of the implications for theory, managerial practice, as well as society in the following.

\subsection{Contribution to the literature on stakeholder democracy}

Our study makes three conceptual contributions to academic theory. First, and foremost, we contribute to the incipient body of empirical research on stakeholder democracy by providing microlevel insights into the customer level. The discussion around stakeholder democracy has, so far, taken place mostly on a normative or conceptual level, but empirical evidence is urgently needed to understand the topic better. Further, most of the discussion on stakeholder democracy has circled the role of employee participation in corporate governance (Cheney, Santa Cruz, Peredo, \& Nazareno, 2014; Dow, 2003; Lower, 2010). Importantly, the existing discussion around stakeholder democracy has already pointed to the potential benefits as well as drawbacks of more democratic governance of corporations and Harrison and Freeman (2004) ask whether corporate democracy is worth the effort. They summarize the pros and cons in the following way (see Table 1).
In line with Harrison and Freeman's (2004) pro arguments, our results reveal that customers would like to have an influence on the companies which they patronize. An involvement of consumers can have manifold positive effects, ranging from a more participatory climate to consumers feeling more responsible for the outcomes of their consumption choices. However, as in the context of involving employees (Cheney, 2002), involving customers can also have drawbacks. The process of involvement costs time and could lead to outcomes that are not in line with the organizations' objectives. Customers could demand more than the company is willing to invest and reluctance to serve the customers' wishes may lead to a backlash. One especially important potential drawback when involving consumers may be that it would be inefficient to involve customers in CSR decisions, because one single customer could never actively take part in the decision making of all the brands that he or she purchases on a daily basis. In this paper, we proposed that companies could offer consumers the choice of whether they would like to be involved or not.

Our study thus contributes to the question concerning the "division of labor" in stakeholder democracy. If stakeholders shall be involved in corporate decision-making in an efficient and meaningful way, the question of who should be involved in which decisions move center stage. The results of our two studies provide an example of how such a division of labor could look like. In CSR decisions, customers would like to be involved in domains that are relevant to their lives but would like to leave other CSR decisions to company-internal CSR managers. It would be a next step to explore which CSR domains have which degrees of relevance for specific company-internal and external stakeholder groups and to design stakeholder involvement processes accordingly. Further, a task to be worked on is to explore ways in which the resulting communication processes could take place. A special role could be played by digital and social media. Premium Cola, a consensus democratic internet collective that has successfully been producing and selling Cola in Europe for more than 18 years, organizes their whole decision-making among 1,600 commercial partners using an online forum. While this sounds complicated, it is, in reality, very efficient. Although all collective members would have the possibility to codecide every decision, they usually only do so for a small number of decisions that

TABLE 1 Potential benefits and drawbacks of stakeholder democracy

Potential benefits

- People like to have a voice, or the ability to influence the organizations in which they work.

- Participation tends to enhance the commitment to the final decisions, which can aid their implementation.

- Democracy in organizations helps people feel more responsible for organizational outcomes.

- Democratic processes can help to create a more participatory climate overall, which may enhance innovation and the ability to change.

- Giving more discretion to employees and managers allows them to develop skills and abilities.

- Practicing democracy is the right thing to do from a moral perspective.

\section{Potential drawbacks}

- People may choose a path that is not advantageous for the organization.

- Democratic processes take time, which can hurt efficiency.

- Implementation of democratic processes demands sweeping organizational changes that are difficult and time-consuming, disrupt the normal business, and might even fail.

- Resistance to democratic processes may come from middle- and upper-level managers.

- Democracy may not fit some situations that require rapid adjustments.

- If practicing democracy reduces organizational performance, it may not be the right thing to do from a moral perspective. 
are relevant to them and for which they feel competent. However, all decisions that are taken are transparent to all members of the stakeholder network and every member of the network could veto a decision that he or she disagrees with. This model of stakeholder democracy would likely be applicable in other contexts as well.

Finally, in this study, we only included the stakeholder group of customers. However, future work packages would include understanding the varying preferences for the involvement of different stakeholder groups.

\section{3 | Contribution to literature on the borders of the organization}

Second, our study contributes to the discussion around the borders of the organization by revealing that company-internal business process CSR versus external philanthropic CSR moderates the beneficial impact of customer involvement in CSR on customer outcomes. We find that whereas customers consider themselves as a part of the organization in areas in which the organization has a strong impact on societal outcomes (i.e., corporate philanthropy), they do not feel competent to comment on CSR domains which mainly concern internal business processes of the corporation (e.g., employment practices). This is an important finding and deserves more academic attention by future studies as, by moving from a shareholder to a stakeholder mindset in management, the previously accepted definition of the "inside" and the "outside" of the organization starts to blur and to be more permeable. While being an internal or external stakeholder of the company seemed to be a given and accepted dichotomy in the past, we should rather speak of stakeholder "proximity" to the core processes of the company from a stakeholder network perspective (e.g., Driscoll \& Starik, 2004; Schons \& Steinmeier, 2016). We specifically see two important avenues for future academic studies here. On the one hand, there is a lack of theory to define this new understanding of organizational boundaries and future research should embark to develop a solid theoretical foundation. On the other hand, empirical research is needed to understand how stakeholders define their roles in stakeholder networks and which types of communication processes, corporate governance structures, and social exchanges result from these relationships.

\subsection{Contribution to literature on organizational identification processes}

Third, and related to this point, our study contributes to the body of research on organizational identification processes (Tsai, Joe, Lin, Chiu, \& Shen, 2015). One central outcome in our study is that customers' identification with the company and dialogue concerning CSR obviously strengthens customers' sense of being an active, contributing element in the organization. Future studies could set out to explore in more detail the psychological mechanisms that underlie this effect. Which sense-making processes are triggered when an organization asks their customers to participate in corporate decision-making and how does this lead to a buildup of organizational identification? It would be especially desirable, although challenging, to conduct longitudinal studies that are able to track these processes dynamically. A specific aspect of our study that would deserve increased attention in the future is the negative effect of involving customers in company-internal, business process-related CSR activities. Why are customers turned off by such an involvement? Analyzing the responses in open text boxes in our study provided first ideas for the psychological rationales underlying this backlash. Some customers stated that, if the company asks them to comment on company-internal business process decisions, these decisions may not be regarded as very important by the management. Thus, instead of communicating the relevance of this topic area, a company may cause the opposite outcome and customers may downgrade the company's intention to make a meaningful contribution. While, based on our study, we can only speculate about these issues, future studies could take our results as a starting point and delve deeper into understanding this question.

\section{6 | LIMITATIONS}

One limitation of our study is that, while the participants in our study reported that they would like to be involved in the CSR decisions of their corporate counterparts, it may be the case that their actual willingness to contribute to such processes is less pronounced. Based on our findings we cannot draw any conclusions about their long-term willingness to engage in such a dialogue. Studies dealing with the consumption of sustainable products have typically reported an attitude-behavior gap (or the "consumer paradox," e.g., Devinney, Auger, Eckhardt, \& Birtchnell, 2006) and this may also prove true for the behaviors studied in the paper at hand. It would be laudable, in future studies, to study consumers' willingness to cocreate corporate decisions, not only in the CSR realm over time and including real measures of behavior.

Further, we investigate the effect that an active involvement of consumers in CSR decision-making has on their identification with the company. However, consumer-company identification may just as well predict consumers' willingness to be a part of a company's decision making. Future studies could set out to test these mechanisms in a longitudinal setting (e.g., using cross-lagged regressions).

\section{1 | Managerial implications}

Our study further generates crucial implications for managers who are facing the task not only to decide on the allocation of corporate philanthropic budgets, but also the redesign of corporate governance mechanisms to be more democratic. Companies are facing internal and 
external pressure to redesign their corporate governance structures as well as their corporate citizenship and CSR programs. Empowerment of various stakeholder groups (O'Dwyer, 2005) and cocreation (Jamali, El Dirani, \& Harwood, 2015) are important keywords in this regard. Companies cannot make do with outdated command-and-control governance systems but have to proactively rethink and redesign how they make and justify their (CSR) management decisions (Vashchenko, 2017). In the area of corporate citizenship management, this becomes very obvious when we take a look at the trend toward more employee volunteering (Dreesbach-Bundy \& Scheck, 2017), social intrapreneurship, collective impact, and cocreation of social projects and programs. To design such new, and agile, approaches to corporate governance in general and CSR management specifically, companies should be open to an ongoing dialogue, be willing to change as a consequence of critical feedback from their stakeholders, and communicate with the various stakeholder groups on eye level.

While in this study results indicated that customers do not wish to be involved in more internal, business-process related decisions, it is, of course, laudable if companies start to make their organization more sustainable using an inside-out approach (Høvring, 2017; Morsing, Schultz, \& Nielsen, 2008). Specifically, rather than merely making donations to good causes and engaging in good corporate citizenship activities, companies should redesign their value chain to contribute to sustainable development as defined in the SDGs. Thus, involving stakeholders as well as transforming the own value chain toward more sustainable business practices can be seen as top priorities for corporate sustainability management in the next years.

Summarizing these two goals, that is, involving stakeholders as well as transforming the own value chain toward more sustainability, the following Figure 3 proposes a $2 \times 2$ matrix with four types of CSR activities.

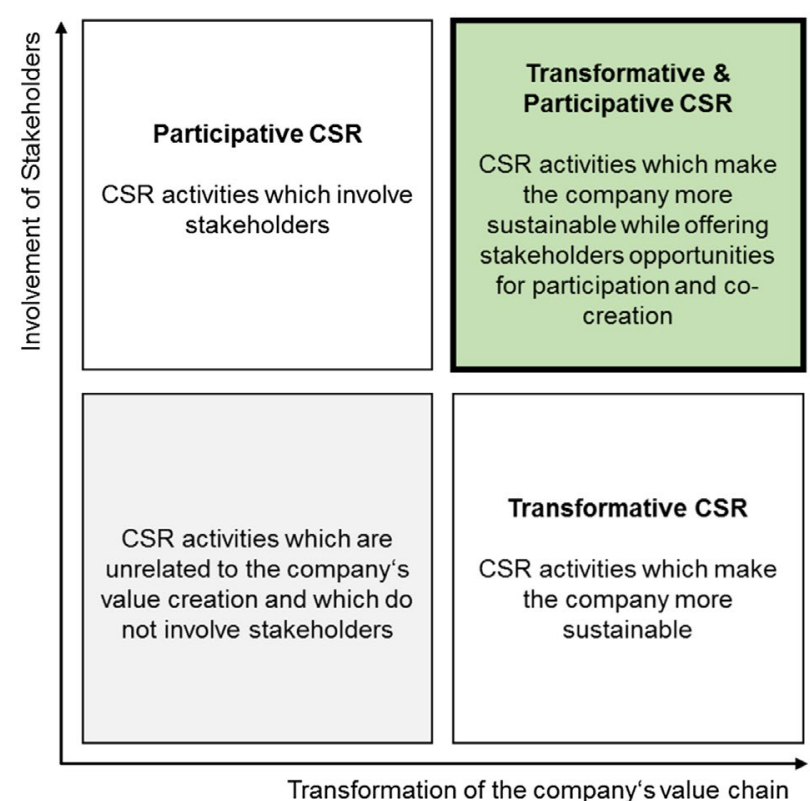

FIGURE 3 Transformative \& participative CSR
The $x$ axis represents the degree of transformation of the own value chain. The $y$ axis represents the degree of involvement of stakeholders in the planning and execution of the activities. Thus, companies can choose to conduct CSR activities that do not transform the own value chain and that do not offer stakeholders opportunities for cocreation and participation (bottom left quadrant). In the past years, some companies have implemented such activities to quickly "hop on the CSR bandwagon," hoping to positively influence stakeholder attitudes. Examples of such activities are donations to good causes that are unrelated to the companies' core business. If companies wish to transform their value chain to be more sustainable but not include stakeholders ("transformative CSR," bottom right), this could be done by, for example, redesigning production processes to be more resource efficient. If companies decide not to change their own business-processes but wish to involve stakeholders ("participative CSR," upper left), this can be done by, for example, making philanthropic donations, while at the same time letting stakeholders decide which causes the money will be donated to. Some companies have recently chosen to do this in cause-related marketing campaigns to enhance stakeholder interest and support (e.g., Amazon's Smile Program). Based on the results of the study at hand, this could be a viable approach to include consumers in the CSR decisions of the company. Last but not least, companies can decide to do both, that is, transform their own business-processes, while involving stakeholders in this process ("Transformative and participative CSR," upper right). Examples for such activities are social intrapreneurship campaigns like BASF's starting ventures or SAP's One Billion Lives. Obviously, for such activities, it makes sense to involve stakeholders who have a high degree of stakeholder proximity, for example, employees.

Such activities can have manifold benefits. Besides their intended social impact, they may strengthen relationships with various stakeholder groups, including employees, customers, investors, suppliers, partner organizations, governments, and the public. They also lead to increases in resource efficiency, thereby often producing tangible cost-savings (Parvatiyar \& Sisodia, 2019). Over and above, they may change the corporate culture in a way that the organization transforms into a purpose-driven enterprise, infusing employees and other stakeholders with a sense of meaningfulness, thereby inspiring innovation and sustainable forms of value creation.

\section{2 | Societal implications}

The paper at hand reveals that more democratic governance of CSR management is no unrealistic ideal anymore. Customers wish to be involved in CSR decisions that are relevant for them and reward companies for doing so by enhanced customer-company identification and loyalty. What we need in the future is more research that sheds light on stakeholders' preferences for involvement, the underlying psychological mechanisms, as well as practical methods of involving stakeholders in a dialogue that benefits the individual stakeholder, the company, and society. Specific questions worth exploring include: how can large corporations move toward more democratic governance processes? How could future models of 
corporate governance look like given that between the classical hierarchical decision-making and full consensus democracy there are many shades of participatory decision processes? How could companies best move toward more participation in a step-by-step approach? The book "Reinventing Organizations" by Frederic Laloux (2014) offers some interesting insights and suggestions. Also, practical examples of more participatory corporate governance models, for example, as in the case of the worker-owned Mondragon Initiatives in Spain (Bernacchio \& Couch, 2015; Flecha \& Santa Cruz, 2011; Forcadell, 2005; Kasmir, 1996; Meek \& Woodworth, 1990; Miller, 2001; Molina \& Miguez, 2008), offer important inspiration and insights.

We already live in a world in which the traditional boundaries of the organizations are transcended in various ways. For instance, customers cocreate products or employees communicate about their day-to-day work activities via social media platforms like Linkedln. Thus, the classical definition of company-internal and company-external stakeholders is already hard to maintain. Given that we are thus moving toward seeing a company as a nexus of stakeholder interests (Griffin, 2017), we should accept that it is high time to move from "managing stakeholders" toward being more transparent and letting deliberation on eye-level be a reality (Richter \& Dow, 2017).

For our societies, however, there are some important caveats which we should consider. As we are currently moving away from a system in which public goods were mainly provided by governments toward a situation in which more and more public goods provision is coordinated via private businesses and corporate foundations, we should be conscious of the potential detrimental societal consequences of these developments.

In the traditional system of public goods provision via states, (a) governments collect taxes, (b) allocate budgets, (c) government bodies use these budgets to provide public goods, (d) these public goods are consumed by citizens, and (e) citizens voice their feedback and needs through voting. In a system in which public goods are provided by private businesses, (a) companies earn money, (b) allocate budgets, (c) provide the public goods (in many cases in collaboration with partner organizations), (d) these public goods are consumed by citizens, and (e) citizens can voice their feedback and needs through purchasing from or boycotting these companies. Figure 4 illustrates these two processes.

Both systems may have benefits and drawbacks, some of which we would like to point to and discuss in the following. Thereby, we will put a special focus on the less established and more contested mechanism of private provision of public goods and discuss it in the light of the role of corporate democracy. Table 2 contains a summary of these arguments (which of course are not meant to be conclusive).

In the case of government provision of public goods, the (a) tax system is in general intended to lead to a fair distribution of the overall tax burden. However, this system might be biased due to tax loopholes. Further, taxes lead to more bureaucracy and a subsequent welfare reduction. In democratic societies, (b) the budget allocation for public goods provision is democratically legitimized. The same applies to the provision (c): it is controlled by democratically legitimized bodies. When consumed (d), public goods that are provided by the government do not have any "strings attached," that is, there is no sponsoring company or foundation that has the agenda to influence and persuade stakeholders. Finally, in democratic societies, (e) citizens can voice their opinion in votes or through active participation and each citizen has the same vote. However, it has to be noted that the effectiveness of the specific public budget allocation mechanisms might be questioned. Also, government provision of public goods might be less efficient than the private provision and may suffer from a performance gap as compared to private solutions.

If we consider systems in which public goods are provided by private businesses, we can envision an extreme case in which these goods are provided by undemocratic, unsustainable, and socially irresponsible companies and an opposite extreme case in which the public goods are provided by democratically governed, sustainable, and socially responsible companies. In the first case, (a) companies would make the profits which they use for the provision of the public goods, while engaging in unsustainable and irresponsible business practices, thereby causing negative externalities. Further, (b) the allocation of budgets for public goods would suffer from a legitimacy gap (i.e., managers are not democratically elected), and the selection would be biased due to extrinsic motives (e.g., companies are motivated by image concerns and stigmatized, less attractive, causes miss out on donations). As a
FIGURE 4 Government versus private provision of public goods
Government versus Private Provision of Public Goods
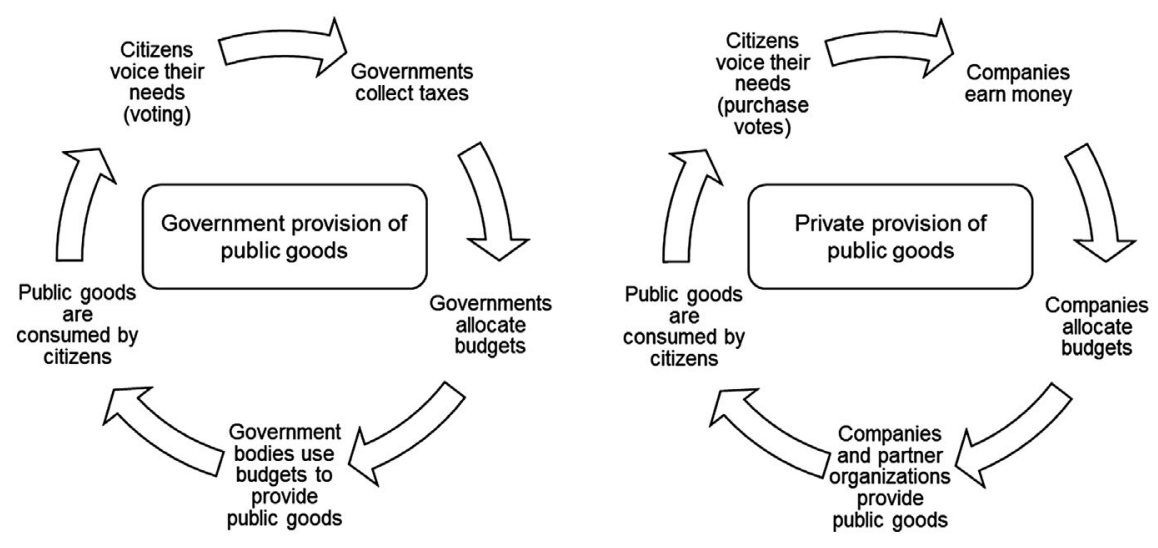
TABLE 2 Government versus private provision of public goods

Government provision of public goods
1.1 Governments collect taxes: tax system is intended
to lead to a fair distribution of tax burden, but the tax
burden might be biased due to tax loopholes, taxes
lead to more bureaucracy and subsequent welfare
reduction

1.2 Governments allocate budgets: in democratic societies, budget allocation is democratically legitimized, but the effectiveness of specific allocation mechanisms might be questioned

1.3 Government bodies use budgets to provide public goods: government provision of public goods is controlled by democratically legitimized bodies, but government provision of public goods might be less efficient than private provision (performance gap)

\section{Private provision: case 1}

2.1 Companies earn money: profits are made while engaging in unsustainable and irresponsible business practices

2.2 Companies allocate budgets: legitimacy gap (managers are not democratically elected to make decisions that concern public welfare), selection is biased due to extrinsic motives (stigmatized causes miss out on donations, social issues gap), and funding might be unreliable, for example, in times of economic crises or if companies go bankrupt

2.3 Companies and partner organizations use budgets to provide public goods: provision of public goods remains superficial and is designed to address meaningless impact metrics like "lives impacted"

2.4 Public goods are consumed by citizens: citizens are exposed to the branding of the sponsoring companies

2.5 Citizens voice their needs: consumers could reward good companies and boycott bad ones but consumer apathy and information asymmetries often render this regulation mechanism ineffective; further, purchase votes favor those with big purchasing power

\section{Private provision: case 2}

3.1 Companies earn money: profits are generated in a socially responsible and sustainable way

3.2 Companies allocate budgets: budget allocation is conducted through the involvement of stakeholders and/or managers are democratically elected to make the decisions, funding is secured through agreements and alliances

\subsection{Companies and partner organiza-} tions use budgets to provide public goods: companies flexibly address urgent sustainability problems and provide effective solutions, especially through collective impact programs, while the impact is measured and monitored in a meaningful way

3.4 Public goods are consumed by citizens: socially responsible companies might consider not to communicate their engagement as a sponsor

3.5 Citizens voice their needs: over and above purchase votes, companies use proactive stakeholder engagement to elucidate the preferences and needs of citizens citizens can voice their opinion in votes or through tive participation, each citizen has the same vote result, the allocation of budgets for public goods would possibly diverge from the preferences of citizens (i.e., a social issues gap would possibly exist). Further, funding might be unreliable, for example, in times of economic crises or if companies go bankrupt. The provision of public goods (c) could remain superficial and could be designed to address meaningless impact metrics like "lives impacted," while citizens are exposed to the branding of the sponsoring companies when they consume the public goods (d). Moreover, (e) consumers could, in theory, reward good companies and boycott bad ones, but consumer apathy, imperfect markets (e.g., monopolies or information asymmetries) often render this regulation mechanism ineffective. Further, a system of purchase votes favors those with big purchasing power and thus leads to unequally distributed opportunities to voice one's opinion. Finally, some companies, for example, business-to-business companies, might not even be possible targets of consumer purchase votes or boycotts. In summary, in such a system, companies might exploit private provision of public goods to manipulate public opinion in their own interests, thereby glossing over condemnable business practices, while maintaining a market system that is neither socially responsible nor sustainable. This threat is very clearly articulated in recent critical publications such as Anand Giridharadas' "Winners Take All" (Giridharadas, 2018).

But how would a "best case" of private provision of public goods look like? Imagining such a system, we could assume companies to (a) make profits in socially responsible and sustainable ways as already done by some exemplary social businesses. The budget allocation (b) could be conducted through the active involvement of stakeholders and managers could be democratically elected to make decisions. In such a system, funding could be secured through agreements and alliances between various actors (e.g., through collective impact programs). Through such carefully designed programs, companies could (c) flexibly address urgent sustainability challenges and provide effective solutions, while impact is measured and monitored in meaningful ways (e.g., moving from output to outcome level; Boateng, Akamavi, \& Ndoro, 2016; Griffin, 2017). While consuming public goods (d), citizens would not necessarily have to be exposed to the advertisement, as socially responsible companies might consider not to directly communicate their engagement as a sponsor to consumers. Communication may happen via other, more unobtrusive, pathways such as annual reports or ratings. Further, (e) over and above purchase votes, in such 
a system, companies could use proactive stakeholder engagement to continuously elucidate the potentially shifting preferences and needs of citizens and make an effort to represent them in a balanced way.

In a perfectly democratic society with effective regulation, the system of public provision of public goods is undoubtedly preferable. However, our societies are suffering from a variety of weaknesses, for example, due to globalized markets with different regulatory environments or the absence of a "world government," In fact, we will not be able to turn back the wheel (Matten, 2009)-a system in which public goods are provided by both, government as well as private bodies is already a reality. To make the best of this situation, we should endeavor to avoid the drawbacks outlined in the "worst case" scenario above. We see one crucial way to do this in pushing companies to renew their corporate governance to be more participatory and democratic. For us as researchers, we see our responsibility in using the methods of academic research to inform and support this development.

\section{CONFLICT OF INTEREST}

The authors declare that they have no conflict of interest.

\section{ORCID}

Laura Marie Edinger-Schons (iD https://orcid.org/0000-0002-8981-3379 Sabrina Scheidler iD https://orcid.org/0000-0001-7691-3736

\section{ENDNOTE}

${ }^{1}$ Additional analyses devoted to potential gender-related differences in the effects are provided in the results section.

\section{REFERENCES}

Ahearne, M., Bhattacharya, C. B., \& Gruen, T. (2005). Antecedents and consequences of customer-company identification: Expanding the role of relationship marketing. Journal of Applied Psychology, 90(3), 574. https://doi.org/10.1037/0021-9010.90.3.574

Aldrich, H., \& Herker, D. (1977). Boundary spanning roles and organization structure. Academy of Management Review, 2, 217-230.

Anderson, S. D., \& Cavanagh, J. (1996). The top 200: The rise of global corporate power. Washington, DC: Institute for Policy Studies.

Bagozzi, R. P., \& Yi, Y. (1988). On the evaluation of structural equation models. Journal of the Academy of Marketing Science, 16(1), 74-94. https://doi.org/10.1007/BF02723327

Becker-Olsen, K. L., Cudmore, B. A., \& Hill, R. P. (2006). The impact of perceived corporate social responsibility on customer behavior. Journal of Business Research, 59, 46-53.

Bernacchio, C., \& Couch, R. (2015). The virtue of participatory governance: A Macntyrean alternative to shareholder maximization. Business Ethics: A European Review, 24, S130-S143.

Boateng, A., Akamavi, R. K., \& Ndoro, G. (2016). Measuring performance of non-profit organisations: Evidence from large charities. Business Ethics: A European Review, 25(1), 59-74.

Body, A., \& Breeze, B. (2016). What are 'unpopular causes' and how can they achieve fundraising success? International Journal of Nonprofit and Voluntary Sector Marketing, 21(1), 57-70.

Callahan, D. (2017). The givers: Wealth, power, and philanthropy in a new gilded age. New York: Alfred A. Knopf.

Cheney, G. (2002). Values at work: Employee participation meets market pressure at Mondragon. Ithaca, NY: Cornell University Press.
Cheney, G., Santa Cruz, I., Peredo, A. M., \& Nazareno, E. (2014). Worker cooperatives as an organizational alternative: Challenges, achievements and promise in business governance and ownership. Organization, 21(5), 591-603. https://doi.org/10.1177/1350508414 539784

Crane, A., Driver, C., Kaler, J., Parker, M., \& Parkinson, J. (2005). Stakeholder democracy: Towards a multi-disciplinary view. Business Ethics: A European Review, 14(1), 67-75.

Crane, A., \& Matten, D. (2010). Business ethics: Managing corporate citizenship and sustainability in the age of globalization (3rd ed.). Oxford: Oxford University Press.

Crane, A., Matten, D., \& Moon, J. (2004). Stakeholders as citizens? Rethinking rights, participation, and democracy. Journal of Business Ethics, 53, 107-122.

Dawkins, C. E. (2014). The principle of good faith: Toward substantive stakeholder engagement. Journal of Business Ethics, 121, 283-295.

Deetz, S. (1992). Democracy in an age of corporate colonization: Developments in communication and the politics of everyday life. Albany, NY: State University of New York Press.

Detomasi, D. (2015). The multinational corporation as a political actor: 'Varieties of capitalism' revisited. Journal of Business Ethics, 128, 685-700.

Devinney, T. M., Auger, P., Eckhardt, G., \& Birtchnell, T. (2006). The other CSR. Stanford Social Innovation Review, 4(Fall), 30; 32-33;-35-37.

Dow, G. K. (2003). Governing the firm: Workers' control in theory and practice. Cambridge University Press.

Dreesbach-Bundy, S., \& Scheck, B. (2017). Corporate volunteering: A bibliometric analysis from 1990 to 2015. Business Ethics: A European Review, 26(3), 240-256.

Driscoll, C., \& Starik, M. (2004). The primordial stakeholder: Advancing the conceptual consideration of stakeholder status for the natural environment. Journal of Business Ethics, 49, 55-73.

Driver, C., \& Thompson, G. (2002). Corporate governance and democracy: The stakeholder debate revisited. Journal of Management and Governance, 6, 111-130.

Du, S., Bhattacharya, C. B., \& Sen, S. (2007). Reaping relational rewards from corporate social responsibility: The role of competitive positioning. International Journal of Research in Marketing, 24, 224-241.

Du, S., Bhattacharya, C. B., \& Sen, S. (2010). Maximizing business returns to corporate social responsibility (CSR): The role of CSR communication. International Journal of Management Reviews, 12, 8-19.

Dürrenberger, G., Kastenholz, H., \& Behringer, J. (1999). Integrated assessment focus groups: Bridging the gap between science and policy? Science and Public Policy, 26, 341-349.

Ellen, P. S., Webb, D. J., \& Mohr, L. A. (2006). Building corporate associations: Customer attributions for corporate socially responsible programs. Journal of the Academy of Marketing Science, 34(2), 147-157.

Fein, S., \& Hilton, J. L. (1994). Judging others in the shadow of suspicion. Motivation and Emotion, 18, 167-198.

Fitchett, J. A. (2005). Consumers as stakeholders: Prospects for democracy in marketing theory. Business Ethics: A European Review, 14(1), 14-27.

Flecha, R., \& Santa Cruz, I. (2011). Cooperation for economic success: The Mondragon case. Analyse \& Kritik, 33(1), 157-170.

Forcadell, F. J. (2005). Democracy, cooperation and business success: The case of Mondragón Corporación Cooperativa. Journal of Business Ethics, 56(3), 255-274.

Forehand, M. R., \& Grier, S. (2003). When is honesty the best policy? The effect of stated company intent on customer skepticism. Journal of Consumer Psychology, 13, 349-356.

Frynas, J. G., \& Stephens, S. (2015). Political corporate social responsibility: Reviewing theories and setting new agendas. International Journal of Management Reviews, 17, 483-509.

Giridharadas, A. (2018). Winners take all: The elite charade of changing the world. Toronto: Knopf. 
Grant, R. R. (1997). Measuring corporate power: Assessing the options. Journal of Economic Issues, 31, 453-460.

Griffin, J. J. (2017). Tracing stakeholder terminology then and now: Convergence and new pathways. Business Ethics: A European Review, 26(4), 326-346.

Harrison, J. S., \& Freeman, R. E. (2004). Special topic: Democracy in and around organizations is organizational democracy worth the effort? The Academy of Management Executive, 18(3), 49-53.

Haumann, T., Quaiser, B., Wieseke, J., \& Rese, M. (2014). Footprints in the sands of time: A comparative analysis of the effectiveness of customer satisfaction and customer-company identification over time. Journal of Marketing, 78(6), 78-102.

Homburg, C., Koschate, N., \& Hoyer, W.D. (2006). The role of cognition and affect in the formation of customer satisfaction: A dynamic perspective. Journal of Marketing, 70(3), 21-31.

Homburg, C., Wieseke, J., \& Hoyer, W. D. (2009). Social identity and the service-profit chain. Journal of Marketing, 73(2), 38-54. https://doi. org/10.1509/jmkg.73.2.38

Høvring, C. M. (2017). Caught in a communicative catch-22? Translating the notion of CSR as shared value creation in a Danish CSR frontrunner. Business Ethics: A European Review, 26(4), 369-381.

ISO 26000: 2010. (2011). ISO, D. 26000: 2011-01-Leitfaden zur gesellschaftlichen Verantwortung. Berlin: Beuth. Retrieved from https ://www.bmas.de/SharedDocs/Downloads/DE/PDF-Publikationen/ a395-csr-din-26000.pdf\%3F_-blob\%3DpublicationFile

Jamali, D. R., El Dirani, A. M., \& Harwood, I. A. (2015). Exploring human resource management roles in corporate social responsibility: The CSR-HRM co-creation model. Business Ethics: A European Review, 24(2), 125-143.

Kasmir, S. (1996). Myth of Mondragon, The: Cooperatives, politics, and working class life in a basque town. New York: SUNY Press.

Kerr, J. L. (2004). The limits of organizational democracy. The Academy of Management Executive, 18(3), 81-95. https://doi.org/10.5465/ ame.2004.14776172

Laloux, F. (2014). Reinventing organizations: A guide to creating organizations inspired by the next stage in human consciousness. Nelson Parker.

Lower, M. (2010). Employee participation in governance: A legal and ethical analysis. Cambridge: Cambridge University Press.

Matten, D. (2009). Review essay: "It's the Politics, Stupid!" Reflections on the role of business in contemporary nonfiction. Business \& Society, 48(4), 565-576.

Matten, D., \& Crane, A. (2005). What is stakeholder democracy? Perspectives and issues. Business Ethics: A European Review, 14, 6-13.

McGoey, L. (2015). No such thing as a free gift: The Gates Foundation and the price of philanthropy. London, UK: Verso.

Meek, C. B., \& Woodworth, W. P. (1990). Technical training and EnterpRse: Mondragon's educational system and its implications for other cooperatives. Economic and Industrial Democracy, 11(4), 505-528.

Miller, M. (2001). Mondragon: Lessons for our times. (Special Feature: Mondragon Cooperatives). Social Policy, 32(2), 17-22.

Molina, F., \& Miguez, A. (2008). The origins of Mondragon: Catholic co-operativism and social movement in a Basque valley (1941-59). Social History, 33(3), 284-298.

Moriarty, J. (2014). The connection between stakeholder theory and stakeholder democracy: An excavation and defense. Business \& Society, 53, 820-852.

Morsing, M. (2006). Corporate social responsibility as strategic auto-communication: On the role of external stakeholders for member identification. Business Ethics: A European Review, 15(2), 171-182.

Morsing, M., \& Perrini, F. (2009). CSR in SMEs: Do SMEs matter for the CSR agenda? Business Ethics: A European Review, 18(1), 1-6.

Morsing, M., \& Schultz, M. (2006). Corporate social responsibility communication: Stakeholder information, response and involvement strategies. Business Ethics: A European Review, 15, 323-338.
Morsing, M., Schultz, M., \& Nielsen, K. U. (2008). The 'Catch 22' of communicating CSR: Findings from a Danish study. Journal of Marketing Communications, 14(2), 97-111. https://doi.org/10.1080/13527 260701856608

Murray, K. B., \& Vogel, C. M. (1997). Using a hierarchy-of-effects approach to gauge the effectiveness of corporate social responsibility to generate goodwill toward the firm: Financial versus nonfinancial impacts. Journal of Business Research, 38, 141-159. https://doi. org/10.1016/S0148-2963(96)00061-6

Nace, T. (2005). Gangs of America: The rise of corporate power and the disabling of democracy. San Francisco, CA: Berrett-Koehler Publishers.

Nielsen, A. E., \& Thomsen, C. (2009). Investigating CSR communication in SMEs: A case study among Danish middle managers. Business Ethics: A European Review, 18(1), 83-93.

Nunnally, J. (1978). Psychometric theory (2nd ed.). New York: McGraw-Hill.

O'Dwyer, B. (2005). Stakeholder democracy: Challenges and contributions from social accounting. Business Ethics: A European Review, 14, 28-41.

Ogilvy Public Relations Worldwide. (2010). Communicating corporate responsibility. Retrieved from http://www.ogilvypr.com/en/conte nt/communicating-corporate-responsibility

Parvatiyar, A., \& Sisodia, R. (Eds.). (2019). Handbook of advances in marketing in an era of disruptions: Essays in Honour of Jagdish N. Sheth. SAGE Publications India

Pérez, A., de los Salmones, M. M. G., \& Liu, M. T. (2019). Maximising business returns to corporate social responsibility communication: An empirical test. Business Ethics: A European Review, 28(3), 275-289.

Podsakoff, P. M., MacKenzie, S. B., Lee, J. Y., \& Podsakoff, N. P. (2003). Common method biases in behavioral research: A critical review of the literature and recommended remedies. Journal of Applied Psychology, 88, 879-903.

Powley, E. H., Fry, R. E., Barrett, F. J., \& Bright, D. S. (2004). Dialogic democracy meets command and control: Transformation through the appreciative inquiry summit. The Academy of Management Executive, 18(3), 67-80. https://doi.org/10.5465/ame.2004.14776170

Reich, R. (2006). Philanthropy and its uneasy relation to equality. In W. Damon \& S. Verducci (Eds.), Taking philanthropy seriously: Beyond noble intentions to responsible giving (pp. 28-49). Bloomington, IN: Indiana University Press.

Reich, R. (2010). Toward a political theory of philanthropy. In P. Illingworth, T. Pogge, \& L. Wenar (Eds.), Giving well: The ethics of philanthropy (pp. 177-195). Oxford: Oxford University Press.

Reich, R. (2012). A failure of philanthropy: American charity shortchanges the poor, and public policy is partly to blame. Voices in Urban Education, 32, 42-48.

Reich, R. (2017). Why big philanthropy needs scrutiny not just gratitude. Retrieved from https://tinyspark.org/podcasts/why-big-philanthro py-needs-scrutiny-not-gratitude/

Richter, U. H., \& Dow, K. E. (2017). Stakeholder theory: A deliberative perspective. Business Ethics: A European Review, 26(4), 428-442.

Roach, B. (2007). Corporate power in a global economy. GDAE teaching modules on social and environmental issues in economics. Retrieved from http://www.ase.tufts.edu/gdae/education_materials/modul es.html\#corporate

Robinson, S. R., Irmak, C., \& Jayachandran, S. (2012). Choice of cause in cause-related marketing. Journal of Marketing, 76(4), 126-139. https ://doi.org/10.1509/jm.09.0589

Santos, F. M., \& Eisenhardt, K. M. (2005). Organizational boundaries and theories of organization. Organization Science, 16, 491-508.

Scherer, A. G., Baumann-Pauly, D., \& Schneider, A. (2013). Democratizing corporate governance: Compensating for the Democratic deficit of corporate political activity and corporate citizenship. Business \& Society, 52, 473-514. https://doi.org/10.1177/0007650312446931

Scherer, A. G., \& Palazzo, G. (2011). The new political role of business in a globalized world: A review of a new perspective on CSR and 
its implications for the firm, governance, and democracy. Journal of Management Studies, 48, 899-931.

Scherer, A. G., Rasche, A., Palazzo, G., \& Spicer, A. (2016). Managing for political corporate social responsibility: New challenges and directions for PCSR 2.0. Journal of Management Studies, 53, 273-298.

Schons, L., \& Steinmeier, M. (2016). Walk the talk? How symbolic and substantive CSR actions affect firm performance depending on stakeholder proximity. Corporate Social Responsibility and Environmental Management, 23, 358-372.

Shimp, T. A. (1997). Advertising, promotion, and supplemental aspects of integrated marketing communication (4th ed.). Fort Worth, TX: Dryden Press.

Simon, F. L. (1995). Global corporate philanthropy: A Strategic framework. International Marketing Review, 12, 20-37.

Tsai, Y. H., Joe, S. W., Lin, C. P., Chiu, C. K., \& Shen, K. T. (2015). Exploring corporate citizenship and purchase intention: Mediating effects of brand trust and corporate identification. Business Ethics: A European Review, 24(4), 361-377.

Turnbull, S. (1994). Stakeholder democracy: Redesigning the governance of firms and bureaucracies. The Journal of Socio-Economics, 23, 321-360.

Useem, M. (1988). Market and institutional factors in corporate contributions. California Management Review, 30(2), 77-88.
Vanhamme, J., \& Grobben, B. (2009). Too good to be true! The effectiveness of csr history in countering negative publicity. Journal of Business Ethics, 85, 273-283.

Vashchenko, M. (2017). An external perspective on CSR: What matters and what does not? Business Ethics: A European Review, 26(4), 396-412.

Verhoef, P. C. (2003). Understanding the effect of customer relationship management efforts on customer retention and customer share development. Journal of Marketing, 67(4), 30-45.

Wagner, T., Lutz, R. J., \& Weitz, B. A. (2009). Corporate hypocrisy: Overcoming the threat of inconsistent corporate social responsibility perceptions. Journal of Marketing, 73(6), 77-91. https://doi. org/10.1509/jmkg.73.6.77

Yoon, Y., Gürhan-Canli, Z., \& Schwarz, N. (2006). The effect of corporate social responsibility (CSR) activities on companies with bad reputation. Journal of Consumer Psychology, 16, 377-390.

How to cite this article: Edinger-Schons LM, Lengler-Graiff L, Scheidler S, Mende G, Wieseke J. Listen to the voice of the customer-First steps towards stakeholder democracy. Business Ethics: A Eur Rev. 2019;00:1-18. https://doi. org/10.1111/beer.12252

\section{APPENDIX A. MEASURES AND SCALE EVALUATION}

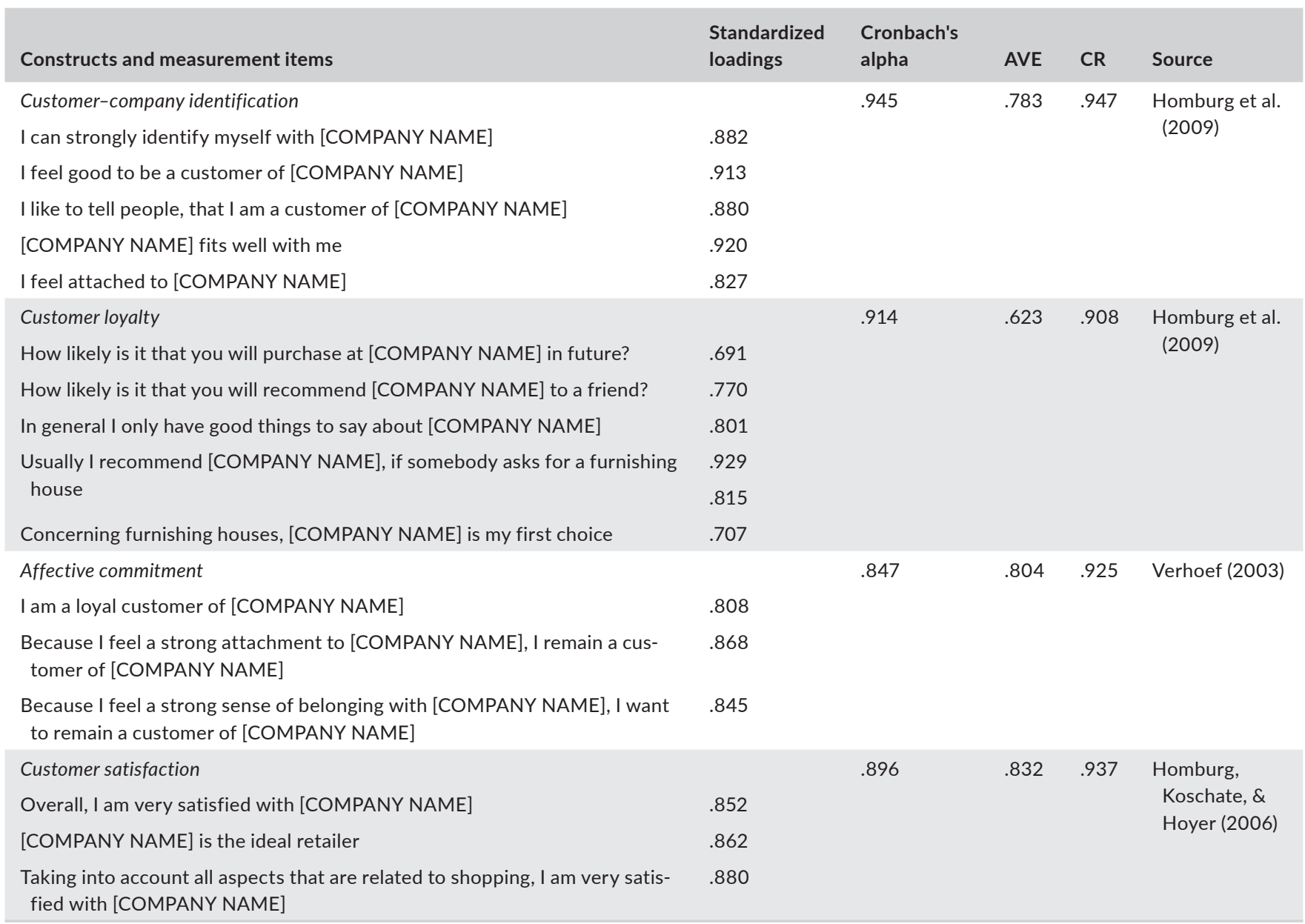




\section{APPENDIX B}

\section{Pretest of the CSR Domain Treatments}

Manipulation checks

\begin{tabular}{|c|c|c|c|c|}
\hline & \multicolumn{2}{|c|}{$\begin{array}{l}\text { Mean Business Process } \\
\text { CSR Group }\end{array}$} & \multicolumn{2}{|c|}{$\begin{array}{l}\text { Mean Philanthropic } \\
\text { CSR Group }\end{array}$} \\
\hline \multicolumn{5}{|l|}{ Business process CSR } \\
\hline [COMPANY NAME] supports their employees through childcare offers & \multicolumn{2}{|l|}{5.81} & \multicolumn{2}{|l|}{4.88} \\
\hline [COMPANY NAME] makes a strong effort to promote their employees' work-life balance & \multicolumn{2}{|l|}{5.76} & \multicolumn{2}{|l|}{4.96} \\
\hline [COMPANY NAME] promotes career opportunities for mothers & \multicolumn{2}{|l|}{5.77} & \multicolumn{2}{|l|}{5.09} \\
\hline [COMPANY NAME] engages in socially responsible business practices for their employees & \multicolumn{2}{|l|}{5.70} & \multicolumn{2}{|l|}{5.17} \\
\hline [COMPANY NAME] promotes their internal social responsibility & \multicolumn{2}{|l|}{5.78} & \multicolumn{2}{|l|}{5.20} \\
\hline \multicolumn{5}{|l|}{ Philanthropic CSR } \\
\hline [COMPANY NAME] donates a part of their profits to good causes & \multicolumn{2}{|l|}{4.89} & \multicolumn{2}{|l|}{5.59} \\
\hline [COMPANY NAME] supports poor children in Pakistan & \multicolumn{2}{|l|}{4.11} & \multicolumn{2}{|l|}{6.03} \\
\hline [COMPANY NAME] engages in philanthropic activities & \multicolumn{2}{|l|}{5.07} & \multicolumn{2}{|l|}{5.74} \\
\hline [COMPANY NAME] engages in socially responsible activities through donations & \multicolumn{2}{|l|}{5.16} & \multicolumn{2}{|l|}{5.72} \\
\hline [COMPANY NAME] promotes their external social responsibility & \multicolumn{2}{|l|}{5.21} & \multicolumn{2}{|l|}{5.74} \\
\hline Pretest of the involvement strategy treatments & $\begin{array}{l}\text { Mean information } \\
\text { group }\end{array}$ & & $\begin{array}{l}\text { feed- } \\
\text { group }\end{array}$ & $\begin{array}{l}\text { Mean } \\
\text { involvement } \\
\text { group }\end{array}$ \\
\hline \multicolumn{5}{|l|}{ Involvement strategy } \\
\hline [COMPANY NAME] informs customers about their social responsibility & 5.64 & 5.35 & & 5.44 \\
\hline $\begin{array}{l}\text { [COMPANY NAME] offers customers the opportunity to provide feedback about their } \\
\text { social responsibility activities }\end{array}$ & 5.30 & 5.51 & & 5.44 \\
\hline [COMPANY NAME] asks customers for their opinion on their social responsibility & 5.17 & 5.26 & & 5.63 \\
\hline [COMPANY NAME] involves customers in developing their social responsibility activites & 5.14 & 5.07 & & 5.43 \\
\hline
\end{tabular}

